\title{
Regional study of anthrax foci
}

\section{Marina Nikolaishvili*, Marina Zakareishvili, Irma Beradze, M donduashvili, Nino Vepkhvadze, Lela Kerdzevadze and Maka Kokhreidze}

Laboratory for the Ministry of Agriculture, Tbilisi, Georgia

\section{Objective}

The purpose of this study was to describe anthrax foci along the Georgia-Azerbaijan border and to describe control measures in identified areas.

\section{Introduction}

Anthrax is endemic in the South Caucasus region. There is a lack of understanding of the regional epidemiology of the causative pathogen, Bacillus anthracis, and the trans-boundary factors related to its persistence.

\section{Methods}

To increase the local and regional understanding of anthrax ecology, ecological risk factors, and the genetic relationships and distribution among Georgian and Azerbaijani B. anthracis strains, a regional study of the ecology of anthrax foci was conducted in Georgia and Azerbaijan. Six regions in Georgia (that border Azerbaijan) were selected for environmental sampling based on historical data. Soil samples were collected in Lagodekhi and Sagarejo and tested at the Laboratory of the Ministry of Agriculture using standard bacteriological and molecular biology methods.

\section{Results}

A total of 185 soil samples were collected. Bacteriological tests revealed four positive samples from Kakheti (two from Lagodekhi, Gelati; two from Dedoplistskaro), from which, cultures were isolated and confirmed by PCR. Georgian scientists continue collecting and testing soil samples. After sample collection and bacteriological testing is completed, the molecular characteristics of the pathogen will be examined.

\section{Conclusions}

This study will assist in the formulation of targeted public health interventions aimed at increasing knowledge of the disease within specific demographics. Public health interventions can focus on livestock surveillance and control in identified areas.

\section{Keywords}

Anthrax; One Health; Endemic; Trans-boundary; Public health

\section{Acknowledgments}

The research study described in this presentation was made possible by financial support provided by the US Defense Threat Reduction Agency. The findings, opinions and views expressed herein belong to the authors and do not reflect an official position of the Department of the Army, Department of Defense, or the US Government, or any other organization listed.

\section{*Marina Nikolaishvili}

E-mail: marina.nikolaishvili@Ima.gov.ge 